\title{
The price for sustainable development of renewable energy sector: the case of Ukraine
}

\author{
Iryna Sotnyk ${ }^{1, *}$, Tetiana Kurbatova ${ }^{2}$, Oleksandr $\mathrm{Kubatko}^{1}$, Yevhen Baranchenko ${ }^{3}$, and Rui $\mathrm{Li}^{4}$ \\ ${ }^{1}$ Sumy State University, Department of Economics, Entrepreneurship and Business Administration, 2 Rymskogo-Korsakova Str., Sumy, \\ 40007, Ukraine \\ ${ }^{2}$ Sumy State University, Department of International Economic Relations, 2 Rymskogo-Korsakova Str., Sumy, 40007, Ukraine \\ ${ }^{3}$ Northumbria University, Department of Entrepreneurship, Innovation and Strategy, Faculty of Business and Law, Sutherland Building, \\ Newcastle-upon-Tyne, NE1 8ST, UK \\ ${ }^{4} \mathrm{Xi}$ 'an University of Finance and Economics, Research Center of Western Energy Economy and Regional Development, Economics \\ Institute, 81 Xiaozhai East Road Xi'an, Shaanxi Province, China
}

\begin{abstract}
While implementing state support mechanisms for renewable energy deployment, each country faces the problem of assessing and forecasting their consequences and must timely adjust their set to ensure sustainable energy development. The article estimates the price for sustainable development of the renewable energy sector on the example of Ukraine based on evaluating the effectiveness of the key mechanism of state support for the industry advancement - the feed-in tariff. The comparison of feed-in tariff rates with the LCOE indicators for the electricity generated from solar and wind power plants has shown that the current feed-in tariffs for two of the most popular renewable energy technologies are inflated several times and do not meet global trends in reducing the cost price of electricity generated by these technologies. The consequence of applying economically unreasonable tariffs is the annual overexpenditures of the state budget of Ukraine, which recently count hundreds of millions of euros. In the context of the country's growing green energy generation, the conditions for further use of the feed-in tariff and the transition to other state support mechanisms are substantiated.
\end{abstract}

\section{Introduction}

Renewable energy (RE) deployment is a progressive trend in modern world development that contributes to the achievement of the Global Sustainable Development Goals \#7 "Affordable and clean energy" and \#13 "Climate action" [1]. However, RE technologies' technical imperfection still causes the high generation cost of green energy compared to its analog generated from fossil fuels. The higher price significantly reduces the RE competitiveness in the global market and hinders the implementation of green energy technologies in business entities and households' everyday activities. Therefore, while developing the RE sector, countries apply state support mechanisms for the RE generation and consumption. The most popular schemes include feed-in tariffs, renewable portfolio standards, net metering, green auctions, tax, financial privileges, etc. [2-8].

When choosing and implementing support instruments, it is advisable to consider the stage of the RE development in a country and the energy policy goals as well as estimate possible social, economic, environmental and political consequences of the introduced levers. Unreasonable and inconsistent application of economic mechanisms for the RE development can not only fail to achieve the state green energy policy goals but also negatively affect the national economy through state budget overspending, deteriorating the investment climate, discouraging business entities and households from introducing RE technologies, etc. In particular, Spain is an example of such a negative experience. In the early 2000s, the country faced a heavy financial burden on the state budget due to high feed-in tariffs introduced for developing the RE sector. To solve the problem, the national legislation was changed, and feed-in tariffs were cut. However, the country was forced to pay compensations to the RE projects' investors close to 1 billion euro on lawsuits won for violations of their rights due to changes in the RE legislation [9]. Thus, each state that implements state support mechanisms for green energy faces assessing and forecasting their consequences and must timely adjust the toolset for the RE sector's sustainable development.

Organizational, legal, economic, and other RE deployment mechanisms in different countries of the world are studied in plenty of research papers, for example $[2-6 ; 10-11 ; 12]$. The authors of $[5 ; 13-15]$ note the high efficiency of the feed-in tariff application at the initial stages of national RE sectors' development since these tariffs could provide sufficient profits to the owners of green energy generating facilities. Therefore, at the expense of feed-in tariffs, it is possible to ensure the RE supply's formation on the domestic energy market. Many scientists indicate that the application of

\footnotetext{
Corresponding author: insotnik@gmail.com
} 
quota obligations or RE portfolio standards is an effective mechanism to provide both supply and demand for green energy [16-19]. However, this scheme must be supported by net metering and financial instruments (in particular, credit lines, partial compensation of loans for the construction of RE facilities by local and state authorities) to encourage active RE development. As the green energy sector expands, it is advisable to use green auctions and tender systems to ensure the creation of a competitive environment in the field [7; 20-22].

Overall, the necessity of evolutionary changes in management mechanisms for sustainable development of the national RE sectors is highly recognized by the researchers. However, few papers examine the feasibility of using specific state support schemes and the criteria for the transition from one tool to another to ensure sustainable RE deployment. As a rule, scientists focus on assessing the benefits and basic parameters of the RE development mechanisms while paying far less attention to the consequences of such incentives for countries' state budgets. For example, E. Dijkgraaf et al. [23] studied the feed-in tariff impact on the green energy advancement by modeling the duration of feed-in tariffs' implementation, their rates, government targets in the RE field, etc. P. del Río [24] evaluated the dynamic efficiency of feed-in tariffs considering technologyspecific fixed-tariffs, their degression in the long-run, cap and floor prices, reductions of support over time for existing RE plants, the burden of green energy costs to consumers, maximum RE plant size, and other factors. The author noted the need to cut feed-in tariffs over time to reduce the financial burden on energy consumers while not quantifying such an impact.

S. Matsuda and H. Kubota [25] proposed the concept of "marginal cost of power facility" to analyze the effectiveness of the feed-in tariff mechanism in Japan. They justified the need to take the effect of replacing imported fossil fuels with green energy into consideration. P. Milanés-Montero et al. [26] analyzed the feed-in tariff influence on Spanish companies' profitability, noting its positive impact on business development. M. D. Leiren and I. Reimer [22] substantiated the transition from feed-in tariffs to green auctions in Germany in a historical institutionalist perspective.

Thus, the recent scientific literature has a gap in research concerning quantitative assessments of the price for sustainable RE sector development based on the feed-in tariff and other economic support tools' use. The lack of these studies negatively affects the effectiveness of national energy policies for the RE advancement, causing management errors and reducing the results of the state support instruments' implementation.

Hence, the purpose of this research is to estimate the price for sustainable development of the RE sector on the example of Ukraine based on evaluating the effectiveness of the feed-in tariff as a key state support mechanism for the industry deployment and justifying the feasibility of its further use in the country. To our knowledge, this is the first attempt to substantiate the feed-in tariff implementation regarding the financial loading on the Ukrainian state budget.

\section{Problems of the feed-in tariff application to ensure sustainable RE development in Ukraine}

Considerably depending on energy import, Ukraine has been actively developing the RE sector over the last decade, using several mechanisms of economic support, including [27]:

1) credit/loan programs offered by commercial banks in Ukraine and the European Bank for Reconstruction and Development (EBRD);

2) tax and customs incentives (value-added tax exemption for equipment and components used for green electricity generation; custom duty exemption for the imported materials, equipment and components used for the production of alternative fuels or green energy);

3) long-term fixed feed-in tariffs;

4) an allowance to feed-in tariffs for using domestic equipment during the RE plants construction;

5 ) the guaranteed purchasing of $100 \%$ of electricity generated from RE sources;

6) free license obligation for connecting household RE plants to the grid;

7) the simplification of the procedure for connecting new RE plants to the electrical grid.

Today the feed-in tariff, which rates are the highest in Europe [28], is the main support scheme used in Ukraine. Legislatively introduced for enterprises in 2008 and households in 2014, the feed-in tariff ensured the active RE development in the domestic business and residential segments in 2009-2020. In particular, the most significant growth in RE capacities and the amount of green electricity generated was in the last 5-6 years (2014-2020) and was caused by several reasons. The first one is high feed-in tariff rates, which are fixed until the end of 2029 and make RE projects economically profitable. The second reason is the $100 \%$ guarantee of green electricity purchase by the state. The third one is the governmental plan to reduce feed-in tariffs gradually in the next decade, which encourages investors to construct RE facilities today and obtain higher feed-in tariffs.

The RE deployment's intensification based on the feed-in tariff application has exacerbated financial problems related to the payments for green electricity generated in the country. The growth of RE generation significantly increases the burden on the state budget. As the legislation of Ukraine does not indicate special sources for the feed-in tariff financing, the rise in the green electricity generation causes an increase in payments for it, which are made at the expense of all taxpayers. This affects the escalation of the weighted average price of electricity in the country, necessitating an increase in electricity tariffs for all consumers. Given the energy poverty of a large part of the Ukrainian population, it threatens to worsen the national socioeconomic situation and provoke social protests.

The issue with the payment for the generated green energy was especially aggravated in spring 2020 during the first lockdown. On the one hand, RE generating capacities continued to operate as usual while the overall 
energy demand decreased due to enterprises' partial shutdown. At that time, it would be expedient to partially turn off the RE facilities and replace expensive green energy with the cheapest one generated by nuclear power plants. However, due to the $100 \%$ guarantee of green electricity purchase by the state, the lack of sufficient maneuverability in the Unified Energy System's capacities, and the reluctance of RE plants owners to lose their profits during the lockdown, the share of expensive RE in the overall energy mix increased significantly. The latter caused the deficit growth of SE "Guaranteed Buyer," which paid for the green energy to its suppliers on behalf of the state. At the end of 2020, this enterprise's deficit reached 24.6 billion hryvnias, threatening the national energy billing system collapse [29]. Hence, the current situation requires reforming the economic mechanisms used to support the RE industry in Ukraine. In particular, it is advisable to move to a green auctions system, which the Ukrainian government has not yet launched due to many obstacles [30].

Another alternative is urgently revising the feed-in tariffs and cutting them to a greater extent than planned by law. However, the reduction of feed-in tariff rates is possible only for new RE projects to keep green energy facilities owners and potential investors' trust. In addition, the feed-in tariffs can be cut only based on an objective assessment of the real cost price of green electricity generation, distribution, and supply regarding the stage of RE technologies development. Suppose such a reduction in feed-in tariff rates does not balance the state budget payments for the generated green electricity. In that case, it is expedient to involve other economic incentives for the RE deployment in Ukraine.

Given the above, the research questions are: (1) whether the current feed-in tariff rates in Ukraine are economically justified in terms of ensuring sustainable RE development; (2) how the changes in feed-in tariff rates and green energy generation volumes affect the financial loading of RE on the state budget and (3) whether it is advisable to involve new economic levers to regulate the national RE sector advancement.

\section{Approaches to assessing the feed-in tariff economic feasibility}

The justification of the feed-in tariff financial burden on the country's state budget can be conducted based on the compliance of the feed-in tariff rates set by the government for a certain RE technology with the average cost price of electricity generated with this technology. In the study, the green energy cost price estimation is based on the Levelized Cost of Electricity (LCOE) method [31]. Carrying out the comparisons for all RE technologies used in the country and determining the weighted average values on their basis make it possible to identify both the degree of feed-in tariffs' justification and their financial burden on the state budget. However, the feed-in tariff rates should be higher than the average cost price of electricity generation for a particular RE technology, as they must at least consider the normal profitability of green energy facilities.
To justify the feed-in tariff rates, the factor of feed-in tariffs' proportionality to the real cost price of green electricity generation $\left(k_{R E i t}\right)$ is proposed. It can be calculated as the ratio of the feed-in tariff for the $i$-th RE technology in the $t$-th year to the cost price of green electricity generated with the $i$-th RE technology in the $t$ th year:

$$
k_{R E i t}=\frac{F I T_{R E I t}}{L C O E_{R E i t}},
$$

where $F I T_{\text {REit }}$ is the feed-in tariff for the $i$-th $\mathrm{RE}$ technology (or the weighted average feed-in tariff for all $\mathrm{RE}$ technologies used in the country) in the $t$-th year, euro/MWh; $L C O E_{\text {REit }}$ is the cost price (calculated with the LCOE method) of green electricity generated with the $i$-th RE technology (or the weighted average cost price of electricity generated with the set of RE technologies used in the country) in the $t$-th year, euro/MWh.

The euro was used to calculate the indicators included in the proportionality factor formula. It is due to the fact that feed-in tariffs are fixed in euros in Ukraine to avoid hryvnia devaluation risks. This precaution guarantees a stable income from the operation of RE generating capacities to their owners.

The proposed proportionality factor reflects the degree of the state pricing policy efficiency in the RE sector in the current period. It can be calculated for both the RE technologies mix used in the country and a certain RE technology. If the proportionality factor values are far from 1, there is a divergence between the feed-in tariff rates and the real cost prices of green electricity generation. It indicates the ineffectiveness of the state pricing policy in the RE field. On the contrary, the convergence of the proportionality factor components and its values close to 1 indicates growing compliance of feed-in tariffs with the real green energy cost price and, accordingly, optimizing the feed-in tariff financial burden on the state budget.

It is important to monitor and analyze the value of the proportionality factor in dynamics as the development of the RE sector technological base can significantly reduce the cost price of green electricity generation over time. It should be reflected in the periodic review and adjustment of feed-in tariff rates in order to reduce state budget expenditures.

The amount of the country's state budget overexpenditures $\left(O E_{\text {sbREit }}\right)$ associated with excessive payments at inflated feed-in tariffs for the $i$-th $\mathrm{RE}$ technology in the $t$-th year can be calculated as:

$$
O E_{s b R E i t}=\left(F I T_{R E i t}-L C O E_{R E i t} \times\left(1+k_{\text {adREit }}\right)\right) \times Q_{R E i t},(2)
$$

where $k_{\text {adREit }}$ is a coefficient that considers additional economically justified factors influencing the increase in the unit price of electricity generated in the $t$-th year with the $i$-th RE technology (for example, the normal profit of the RE facility owner, the risk of doing business in the country, credit risks, etc.); $Q_{R E i t}$ is the amount of green electricity generated in the $t$-th year with the $i$-th RE technology. 
The amount of the state budget over-expenditures can be calculated both for an individual RE technology and their set used in the country. Over time, the growth of this indicator shows an increase in unreasonable state budget expenditures due to unbalanced feed-in tariffs.

\section{Evaluation of the feed-in tariffs' economic feasibility in Ukraine}

Based on the above indicators, let us assess how reasonable the Ukrainian feed-in tariffs and the corresponding state budget expenditures are on the example of large solar power plants (with a capacity of more than $10 \mathrm{MW}$ ) and wind power plants (with a capacity of more than $2000 \mathrm{MW}$ per turbine). Solar and wind power plants have been chosen for calculations due to the following considerations. First, feed-in tariffs for solar and wind power plants in Ukraine are the highest compared to other RE technologies. Attractive tariffs have led to the predominant development of solar and wind power facilities, which today provide most of the green electricity generation. Accordingly, state payments for them are the largest. Second, the cost price of generating electricity for large solar and wind power plants is lower than for small and medium-sized RE facilities that should be reflected in feed-in tariffs. Third, the last decade has been marked by significant progress in reducing the cost price of solar and wind energy technologies on the world market. Therefore, it is important to ensure that the change in feed-in tariffs is consistent with the downward trend in these technologies' cost prices (other things being equal) since the growing volume of green electricity generation significantly affects the state budget expenditures.

The initial data for assessing the economic feasibility of feed-in tariffs for large solar and wind power plants are given in Table 1. Data on LCOE [32-33] are provided in euros, taking into account the euro/US dollar exchange rate of the European Central Bank [34] in the relevant period.

Table 1. Initial data for feed-in tariffs' economic justification (developed by the authors based on [27; 32-33]).

\begin{tabular}{|c|c|c|c|c|}
\hline \multirow{2}{*}{ Year } & \multicolumn{2}{|c|}{$\begin{array}{c}\text { Feed-in tariff on electricity, } \\
\text { euro cent/kWh }\end{array}$} & \multicolumn{2}{c|}{$\begin{array}{c}\text { LCE, } \\
\text { euro cent/kWh }\end{array}$} \\
\cline { 2 - 5 } & SPP* & WPP** & SPP & WPP \\
\hline 2009 & 25.85 & 11.31 & 25.74 & 9.68 \\
\hline 2010 & 25.85 & 11.31 & 18.71 & 9.35 \\
\hline 2011 & 25.85 & 11.31 & 11.28 & 5.10 \\
\hline 2012 & 25.85 & 11.31 & 9.73 & 5.60 \\
\hline 2013 & 18.85 & 11.31 & 7.83 & 5.27 \\
\hline 2014 & 18.85 & 11.31 & 5.95 & 4.44 \\
\hline 2015 & 16.96 & 10.18 & 5.86 & 4.96 \\
\hline 2016 & 15.99 & 10.18 & 4.97 & 4.25 \\
\hline 2017 & 15.03 & 10.18 & 4.43 & 3.98 \\
\hline 2018 & 15.03 & 10.18 & 3.64 & 3.56 \\
\hline 2019 & 15.03 & 10.18 & 3.57 & 3.66 \\
\hline
\end{tabular}

Table notes: * $\mathrm{SPP}$ - solar power plants with a capacity of more than $10 \mathrm{MW}$; **WPP - wind power plants with a capacity of more than $2000 \mathrm{MW}$ per turbine.
Fig. 1 presents the results of calculating the proportionality factors of feed-in tariffs to the real cost price of green electricity generation obtained on the LCOE basis for two RE technologies, according to formula (1).

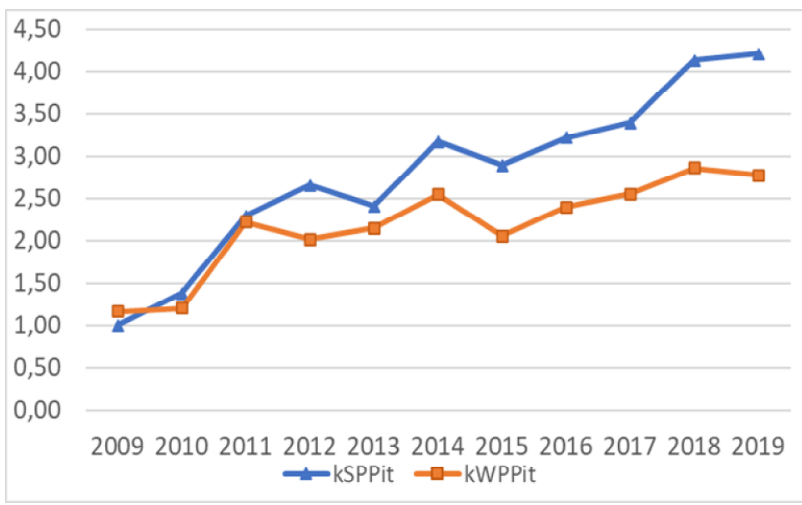

Fig. 1. Proportionality factors of feed-in tariffs to the real cost price of green electricity generation (by the LCOE method) for solar power plants (capacity of more than $10 \mathrm{MW}, k_{S P P i t}$ ) and wind power plants (capacity of more than $2000 \mathrm{MW}$ per turbine, $k_{\text {WP }}$ ) in Ukraine in 2009-2019 (calculated by the authors).

The calculations show that the feed-in tariff for solar power plants with more than $10 \mathrm{MW}$ capacity was almost equal to LCOE in 2009 while slightly exceeding its value. In that year, the feed-in tariff for wind power plants with a capacity of more than $2000 \mathrm{MW}$ per turbine exceeded LCOE by $17 \%$, which is acceptable in ensuring a normal return on the investment and considering the risks of doing business in the country. Thus, the starting feed-in tariff rates were economically justified. During the study period, there was an increase in the divergence between feed-in tariffs and LCOE for the corresponding RE technologies. This is evidenced by the growing values of the proportionality factors. In 11 years, the gap between feed-in tariff and LCOE for solar energy increased to 4.21 times, whereas for wind power plants up to 2.78 times in 2019. Thus, in 2009-2019, there were formed essential reserves to reduce feed-in tariff rates. They indicate the state RE pricing policy's inefficiency and the economic unreasonableness of current feed-in tariffs, which are significantly inflated and need to be corrected. The obtained results are consistent with the trends of cutting feed-in tariffs in the 2000 s by developed countries' governments, which actively deploy the RE sector, due to the cost price reduction of RE technologies [22; 35].

\section{Estimation of financial over- expenditures of the state budget of Ukraine due to inflated feed-in tariffs}

To calculate the state budget over-expenditures for each of the two considered RE technologies in 2009-2019 due to inflated feed-in tariffs, it is necessary to make several assumptions. First, taking into account the Ukrainian realities (credit risks, the profitability of the green energy business, and other factors), economically justified feed- 
in tariffs should exceed the cost price (LCOE) at least by $25 \%$. Thus, $k_{\text {adREit }}=0.25$. Secondly, the calculations will be performed only for the business sector, excluding households as the technical, economic, and other operating conditions of RE facilities for these two types of energy suppliers differ significantly. Third, open and detailed statistical data concerning green energy generation by solar power plants with a capacity of more than $10 \mathrm{MW}$ and wind power plants with a capacity of more than 2000 MW per turbine are absent for 20092019. Therefore, it is assumed that all volumes of green energy generated by solar business facilities were provided by the operation of solar power plants with the capacity of more than $10 \mathrm{MW}$. The same assumption is applied to the green electricity generated by wind energy facilities. Feed-in tariffs for large power plants are usually lower than for smaller power plants, considering lower specific fixed and investment costs. Therefore, our estimates of budget overruns, calculated for the entire energy generation of the respective solar or wind sector, can be counted as the state budget financial losses' minimum threshold. The results of calculations according to formula (2) are given in Table 2.

Table 2. Estimates of the state budget over-expenditures on electricity generated by solar and wind power plants in Ukraine in 2009-2019 due to inflated feed-in tariffs (calculated by the authors based on [36-42]).

\begin{tabular}{|c|c|c|c|c|c|c|}
\hline \multirow{2}{*}{$\begin{array}{c}\text { Year, } \\
t\end{array}$} & \multicolumn{3}{|c|}{ Solar energy sector } & \multicolumn{3}{|c|}{ Wind energy sector } \\
\hline & $\boldsymbol{K}_{\text {adSPPt }}$ & $\begin{array}{c}Q_{S P P t} \\
\text { mln } \\
\text { kWh }\end{array}$ & $\begin{array}{c}O E_{s b S P P t} \\
\text { thousan } \\
\text { d euro }\end{array}$ & kadWPPt & $\begin{array}{l}Q_{W P P t} \\
\text { mln } \\
\text { kWh }\end{array}$ & $\begin{array}{c}O E_{\text {sbWPPt, }} \\
\text { thousan } \\
\text { d euro }\end{array}$ \\
\hline 2009 & 0.25 & 0.0 & $0^{*}$ & 0.25 & 41.1 & $0 *$ \\
\hline 2010 & 0.25 & 0.5 & 12 & 0.25 & 49.2 & $0 *$ \\
\hline 2011 & 0.25 & 30.0 & 3526 & 0.25 & 89.0 & 4392 \\
\hline 2012 & 0.25 & 334.0 & 45720 & 0.25 & 257.5 & 11085 \\
\hline 2013 & 0.25 & 562.8 & 50999 & 0.25 & 636.4 & 30049 \\
\hline 2014 & 0.25 & 485.2 & 55394 & 0.25 & 1171.5 & 67462 \\
\hline 2015 & 0.25 & 475.2 & 45795 & 0.25 & 973.7 & 38788 \\
\hline 2016 & 0.25 & 492.2 & 48132 & 0.25 & 924.5 & 45045 \\
\hline 2017 & 0.25 & 714.7 & 67879 & 0.25 & 973.5 & 50630 \\
\hline 2018 & 0.25 & 1080.0 & 113171 & 0.25 & 1180.2 & 67680 \\
\hline 2019 & 0.25 & 2932.0 & 309728 & 0.25 & 2022.0 & 113274 \\
\hline
\end{tabular}

Table notes: $k_{a d S P P t}, k_{a d W P P}$ are coefficients of additional energy price factors for solar and wind power plants respectively; $Q_{S P P t}, Q_{W P P t}$ are amounts of green electricity generated by solar and wind power plants respectively; $O E_{s b S P P t}, O E_{s b W P P t}$ are the state budget over-expenditures for feed-in tariffs for solar and wind power plants respectively; $0^{*}$ means no overspending.

Thus, the obtained data (Table 2) show an exponential increase in state budget overruns for green electricity generated by solar facilities in 2016-2019, while budget over-expenditures for green electricity generated by wind turbines are much lower. In particular, in 2018, with the ratio of electricity generation by solar and wind power plants $0.92: 1$, the proportion of state budget overruns was 1.67:1. This indicates extremely high feed-in tariffs for solar energy even compared to feed-in tariffs for wind energy, which are also inflated. It confirms that Ukrainian legislators do not monitor the downward trend in the cost price of electricity generation from renewables and do not adjust feed-in tariffs on time. The result is irrational spending of taxpayers' money, which is recently counted of millions of euros. Today all Ukrainians pay for green energy, and only a few oligarchic clans receive extra profits from it. It threatens the sustainable development of the RE industry in the near future.

It is worth noting that each country, which deploys green energy through the feed-in tariff introduction, faces the problem of budget overspending due to the RE volumes' growth and high feed-in tariffs. In particular, Spain, Germany, the Netherlands, and other developed states had to solve this issue at a certain stage of their RE advancement $[9 ; 22 ; 35]$. A national government's task is to monitor the existing feed-in tariffs' compliance with trends in reducing the green energy cost price. On this basis, the government should timely adjust the set and parameters of state support instruments for RE development while avoiding or minimizing state budget overspending.

\section{Prospects for change of feed-in tariffs in Ukraine}

Based on the data from Table 1, in 2019, the cost prices of generating electricity from solar energy became lower than from wind energy for the considered types of solar and wind power plants for the first time. While maintaining the current trends of cheapening technologies until 2030 (Fig. 2), the cost price of solar energy generation per unit will be 1 euro cent $/ \mathrm{kWh}$, and the cost price of wind energy generation per unit will be 2 euro cents/kWh. In addition, both green energy cost price indicators will be lower than their analogs for energy generated from non-renewable sources.

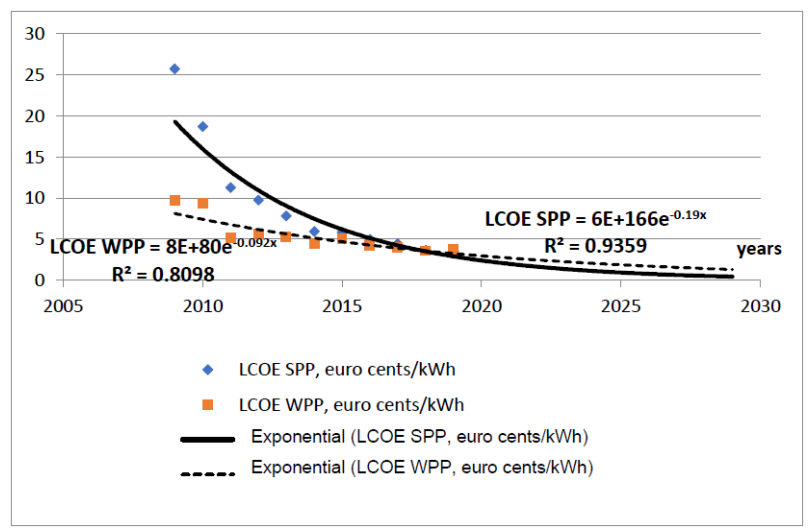

Fig. 2. Cost price reduction forecast of green electricity generation (by the LCOE method) for solar power plants (capacity of more than $10 \mathrm{MW}, L C O E S P P$ ) and wind power plants (capacity of more than $2000 \mathrm{MW}$ per turbine, $L C O E$ $W P P$ ) in 2020-2029 (calculated by the authors).

According to the planned decline in feed-in tariff rates in Ukraine in 2021-2029, the lowest feed-in tariff will be 12.01 euro cents $/ \mathrm{kWh}$ for the considered solar power plant type and 7.92 euro cents $/ \mathrm{kWh}$ for the considered wind power plant type starting 2025 [27]. Compared to the forecast data on LCOE, feed-in tariff 
rates will be several times higher than the expected LCOE for the two RE technologies. That is, in the absence of the further legislative revision of the feed-in tariff rates, the divergence between tariffs and the real cost price of green energy generation will increase. The consequence will be continuing excessive growth in the state budget overspending covered by Ukrainian taxpayers.

Given the projected significant reduction in the cost of green electricity, the latter may gradually become a real competitor for traditional electricity. Under such conditions, the feed-in tariff as an economic support instrument for the development of solar power plants with a capacity of more than $10 \mathrm{MW}$ and wind power plants with a capacity of more than 2000 MW per turbine will exhaust itself. It should be abolished for new similar projects in the RE field in Ukraine. However, the feed-in tariff may be preserved for small and mediumsized RE plants, which have a higher cost price of green electricity generation. Relevant practices for small RE facilities are successfully used by many countries worldwide, ensuring the decentralization of energy supply by involving green energy sources [22; $24 ; 35$; 43].

\section{Conclusions}

The study results on the example of large solar and wind power plants show that current feed-in tariffs in Ukraine are inflated several times and do not correspond to the economically justified level. Such an imbalance in pricing policy for the RE sector causes the disproportionate development of large green energy capacities in the country and devastates the state budget, the losses of which are already estimated at hundreds of millions of euros. Today ordinary Ukrainians pay an exorbitant price for green energy. Preservation of existing and planned reduction of feed-in tariff rates threatens sustainable RE sector development and may cause the industry's financial crisis.

On the one hand, to avoid the mentioned negative consequences, it is advisable to revise the current feed-in tariffs and bring them in line with global trends of the cost price reduction for green electricity generation. However, it is important to consider the additional factors that can increase the unit price for green electricity and refer to the conditions of doing $\mathrm{RE}$ business in Ukrainian realities.

On the other hand, with the preservation of feed-in tariffs, the amount of electricity generated by RE facilities operating on feed-in tariffs will only increase. Consequently, state budget expenditures will rise further even with fair feed-in tariffs. Therefore, it is necessary to gradually move away from using the feed-in tariff mechanism, which ensured the successful start of RE development in Ukraine, and apply other levers to regulate sustainable RE development. The latter may include introducing green auctions, renewable portfolio standards, net metering, green certificates market, and other instruments, which will ensure the continued sustainable advancement of the RE sector without creating excessive loading on the Ukrainian state budget.

The publication was prepared in the framework of the research projects "Formation of economic mechanisms for sustainable development of renewable energy in the conditions of global and local threats to energy security of Ukraine" (No. 0120U104806) and "Stochastic modeling of road map for harmonizing national and European standards for energy market regulation in the transition to a circular and carbon-free economy" (No. 0120U104807) funded by the National Research Foundation of Ukraine.

\section{References}

1. Take action for the Sustainable Development Goals, UN.

https://www.un.org/sustainabledevelopment/sustaina ble-development-goals/ (2020). Accessed 11 Dec 2020.

2. Z. Abdmouleh, R. A. M. Alammari, A. Gastli. Renew. Sustain. Energy Rev. 45, 249-262 (2015)

3. L. A. Barroso, C. Batlle, Review of support schemes for renewable energy sources in South America. https://repositorio.comillas.edu/rest/bitstreams/1689 2/retrieve (2011). Accessed 11 Dec 2020.

4. G. S. Chebotareva. WIT Trans. Ecol. Environ. 217, 881-891 (2018)

5. K. Cory, T. Couture, C. Kreycik, Feed-in tariff policy: design, implementation, and RPS policy interactions.

https://www.nrel.gov/docs/fy09osti/45549.pdf (2009). Accessed 12 Dec 2020

6. K. Hogg, R. O'Regan, Renewable energy support mechanisms: an overview, https:/www.globelawandbusiness.com/storage/files/ books/1259-58d4fdcbcd6d1.pdf. Accessed 11 Dec 2020

7. T. Kurbatova, R. Sidortsov, I. Sotnyk, O. Telizhenko, T. Skibina, H. Roubík. Probl. Perspect. Manag. 17(3), 464-476 (2019)

8. I. Sotnyk, T. Kurbatova, V. Dashkin, Y. Kovalenko. Int. J. of Sustain. Energy 39(3), 218-239 (2020)

9. V. Yaremko, A. Stetsenko, Feed-in tariff in Ukraine https://sk.ua/ru/publications-ru/zelenyi-tarif-vukraine-na-angliiskom/ (2020). Accessed 23 Dec 2020

10. T. Kurbatova, I. Sotnyk, H. Khlyap, Renew. Sustain. Energy Rev. 31, 486-491 (2014)

11. X. Yang, L. He, Y. Xia, Y. Chen. Energy Policy 132, 156-166 (2019)

12. I. Sotnyk, L. Sineviciene, A. Lakstutiene, O. Kubatko, in Proceedings of the 2017 Int. Conf. "Economic Science for Rural Development", Jelgava, April 2017 45, 213-220 (2017)

13. T. Couture, Y. Gagnon. Energy Policy 38(2), 955965 (2010)

14. J. Huenteler. Renew. Sustain. Energy Rev. 39, 857873 (2014) 
15. L. Li, J. Liu, L. Zhu, X.-B. Zhang. Int. J. of Prod. Research 58(14), 1-15 (2019)

16. S. Espey. Energy Policy 29(7), 557-566 (2001)

17. C. Schelly. Energy Policy 67, 543-551 (2014)

18. G. B. Upton, B. F. Snyder. Energy Econ. 66, 205216 (2017)

19. Q. Y. Yan, Q. Zhang, L. Yang, X. Wang, IOP Conf. Series: Earth and Environ. Science 40(1), 12076 (2016)

20. M. Hustveit, J. Sveen, F. Fleten. Energy 141, 17171727 (2017)

21. H. Lucas, R. Ferroukhi, D. Hawila, Renewable Energy Auctions in Developing Countries (IRENA, Abu Dhabi, 2013)

22. M. D. Leiren, I. Reimer. Energy Research \& Social Science 43, 33-40 (2018)

23. E. Dijkgraaf, T. P. Van Dorp, Emiel Maasland. The Energy Journal 39(1), 81-99 (2018)

24. P. del Río. Energy Policy 41, 139-151 (2012)

25. S. Matsuda, H. Kubota. Advanced Materials Research 1117, 307-310 (2015)

26. P. Milanés-Montero, A. Arroyo-Farrona, E. PérezCalderón. Sustainability 10, 3427 (2018)

27. On electricity market, Verkhovna Rada of Ukraine https://zakon.rada.gov.ua/laws/show/2019-19 (2020). Accessed 22 Dec 2020

28. Renewable energy feed-in tariffs, OECD.stat https://stats.oecd.org/Index.aspx?DataSetCode=RE FIT (2020). Accessed 24 Dec 2020

29. Explanatory note to the draft Law of Ukraine "On amendments to certain legislative acts of Ukraine concerning the conditions of sustainable operation of a guaranteed buyer", Liga zakon. http://search.ligazakon.ua/1_doc2.nsf/link1/GI04456 A.html (2021). Accessed $1 \overline{7}$ Feb 2021

30. Green auctions will be launched next year - Ministry of Energy, Economichna Pravda. https://www.epravda.com.ua/news/2020/06/12/6617 37/ (2020). Accessed 23 Dec 2020

31. Levelized Cost of Energy (LCOE), CFI. https://corporatefinanceinstitute.com/resources/kno wledge/finance/levelized-cost-of-energy-lcoe/ (2020). Accessed 26 Dec 2020

32. Lazard's Levelized Cost of Energy Analysis Version 13.0. https://www.lazard.com/media/451086/lazardslevelized-cost-of-energy-version-130-vf.pdf (2019). Accessed 25 Feb 2021.

33. M. Hrytsyshyna, What is wrong with the feed-in tariff? Yurydychna Gazeta. https://yurgazeta.com/publications/practice/energetichnepravo/shcho-ne-tak-iz-zelenim-tarifom.html (2020). Accessed 26 Dec 2020.

34. ECB euro reference exchange rate: US dollar (USD), European Central Bank. https://www.ecb.europa.eu/stats/policy_and_exchan ge_rates/euro_reference_exchange_rates/html/eurof xref-graph-usd.en.html (2020). Accessed 27 Dec 2020

35. A. Held, M. Ragwitz, M. Gephart, E. de Visser, C. Klessmann, Design features of support schemes for renewable electricity: Task 2 report. https://ec.europa.eu/energy/sites/ener/files/document s/2014_design_features_of_support_schemes.pdf (2014). Accessed 4 Mar $20 \overline{2} 1$.

36. Report on the results National Commission for State Regulation of Energy and Public Utilities (NSREPU) activity in 2014: decree of No.971, 31.03.2015, NCSREPU. http://www.nerc.gov.ua/data/filearch/Catalog3/Rich nyi_zvit_2014.pdf (2015). Accessed 22 Dec 2020

37. Report on the results National Commission for State Regulation of Energy and Public Utilities (NSREPU) activity in 2015: decree of No.515, 31.03.2016, NCSREPU. https://www.nerc.gov.ua/data/filearch/Catalog3/Ric hnyi_zvit_NKREKP_2015.pdf (2016). Accessed 22 Dec 2020

38. Report on the results National Commission for State Regulation of Energy and Public Utilities (NSREPU) activity in 2016: decree of No.460, 30.03.2017, NCSREPU. https://www.nerc.gov.ua/data/filearch/Catalog3/Ric hnyi_zvit_NKREKP_2016.pdf (2017). Accessed 22 Dec 2020

39. Report on the results National Commission for State Regulation of Energy and Public Utilities (NSREPU) activity in 2017: decree of No.360, 23.03.2018, NCSREPU. https://www.nerc.gov.ua/data/filearch/Catalog3/Ric hnyi_zvit_NKREKP_2017.pdf (2018). Accessed 22 Dec 2020

40. Report on the results National Commission for State Regulation of Energy and Public Utilities (NSREPU) activity in 2018: decree of No.440, 29.03.2019, NCSREPU. http://www.nerc.gov.ua/data/filearch/Catalog3/Rich nyi_zvit_NKREKP_2018.pdf (2019). Accessed 22 Dec 2020

41. Report on the results National Commission for State Regulation of Energy and Public Utilities (NSREPU) activity in 2019: decree of No.975, 27.05.2020, NCSREPU. https:/www.nerc.gov.ua/data/filearch/Catalog3/Ric hnyi_zvit_NKREKP_2019.pdf (2020). Accessed 22 Dec 2020

42. Information on capacity and volumes of electricity generation by renewable energy plants with the established feed-in tariff (as of 01.01.2020), SAEE https://saee.gov.ua/sites/default/files/VDE_2019.pdf (2020). Accessed 22 Dec 2020

43. B. Speer, Feed-in tariff cost containment: a summary of three primary policy mechanisms. https://cleanenergysolutions.org/news/blog/feedtariff-cost-containment-summary-three-primarypolicy-mechanisms (2011). Accessed 4 Mar 2021 